\title{
History and Current Status of Sugarcane Breeding in Egypt
}

\author{
Eid. M. Mehareb ${ }^{1}$ (1) A. M. A. El-Shafai ${ }^{1}$ - F. M. AboElenen Fouz ${ }^{1}$
}

Received: 4 November 2020/Accepted: 15 May 2021/Published online: 28 June 2021

(C) The Author(s) 2021

\begin{abstract}
Sugarcane has been cultivated in Egypt since $641 \mathrm{AD}$ and is a source of raw material to various agrobased industries. The development of new varieties of sugarcane from controlled crosses in Egypt has developed greatly during recent decades with the majority of the present commercial varieties originating from the local breeding program. Egyptian sugarcane breeding program objectives are high cane and sugar yield, early maturing, good ratooning ability, resistance and tolerance to pests as well as diseases. This program depends on artificial flowering at Giza Research Station (latitude of $30.01^{\circ} \mathrm{N}$ and longitude of $31.20^{\circ} \mathrm{E}$ ) and natural flowering at Sabahia Research Station, Alexandria (latitude of $31^{\circ} 12 \mathrm{~N}$ and longitude of $29.57^{\circ} \mathrm{E}$ ). There are four stations for selection trials, extending from middle to southern Egypt, namely Mallawi (Minia governorate), Shandaweel (Sohag governorate), Mattana Station (Luxor governorate), and Kom Ombo (Aswan governorate), respectively. Current sugar production in Egypt is about 2.458 million tons with $62.2 \%$ from sugar beet and $37.8 \%$ from sugarcane.
\end{abstract}

Keywords Sugarcane $\cdot$ Breeding $\cdot$ Natural . Flowering and selection

Eid. M. Mehareb

elmoharb@yahoo.com

1 Sugar Crops Research Institute (SRCI), Agricultural Research Center (ARC), Giza, Egypt

\section{Introduction}

Sugarcane (Saccharum spp. hybrids) is a major cash and industrial crop in Egypt. It has been cultivated since 641 $\mathrm{AD}$, following the introduction of the crop by the Arabs. Sugarcane is currently grown along the Nile River, from Minia governorate, Middle Egypt (latitude of $27.73^{\circ} \mathrm{N}$ and longitude of $30.84^{\circ} \mathrm{E}$ ) and, south to Aswan governorate in Egypt $\left(24.46^{\circ} \mathrm{N}\right.$ and longitude of $\left.32.93^{\circ} \mathrm{E}\right)$. Sugarcane was the only raw material used for sugar production in Egypt until 1982, when sugar beet was first grown on a small scale. However, by 2012, sugar beet production had increased and produced $50.1 \%$ of the total sugar yield (2.004 million tons). In 2019, 62.2\% and $37.8 \%$ of 2.458 million tons of sugar were extracted from sugar beet and sugarcane, respectively (Table 1). Egypt suffers from the scarcity of water resources, which makes it difficult to expand the area planted under sugarcane (almost fixed at 135,000 ha) due to its high water requirement in Egyptian condition, while sugar beet, as a winter crop, can be grown in the newly reclaimed soils under modern surface irrigation systems (Anonymous 2019). In Egypt, sugarcane crop is fully irrigated using water mainly from the Nile river.

The economic income in south Egypt, is greatly dependent on sugarcane production. Any disturbances to the sugarcane zone would directly impact the livelihoods of the estimated 200,000 families that plant sugarcane. Given an average family size of 5.3 persons, just above a million persons are directly dependent on sugarcane production. Additional 300,000 families that depend on the supplementary businesses around sugar production would also be indirectly affected by a downturn in the industry (USDA GAIN Report 2019). There are three organizations responsible for sugarcane 
Table 1 Basic statistics and information of current sugarcane industry in Egypt

\begin{tabular}{ll}
\hline Current total area growing sugarcane & 104.2 thousand ha \\
Average yield in past five years (t/ha) & $91.7 \mathrm{t} / \mathrm{ha}$ \\
$\begin{array}{l}\text { Average commercial cane sugar } \\
\text { content (\%) }\end{array}$ & $10.5-11.0 \%$ \\
Average number of ratoon crops & 5 ratoons \\
Total sugar production & $0.930 \mathrm{MT}$ \\
$\%$ of area mechanically harvested & - \\
Number of sugar mills & Eight \\
Major diseases and pests & Borers, soft scale insects and \\
& smut \\
Major abiotic stresses & - \\
$\%$ of area irrigated and rainfed & $100 \%$ irrigated
\end{tabular}

breeding and production in Egypt, and they are presented in Table 2.

\section{History of Sugarcane Improvement in Egypt}

Sugarcane varieties are considered the corner stone in cane sugar production. At the beginning in 1868, the massive government-supported sugar industry in Egypt relied for a long time on importing commercial cane varieties from other countries for cultivation (Table 3). In 1913, when a Sugarcane Research Section was established within the Department of Agriculture, sugarcane seeds were obtained from sugarcane experimental stations in Hawaii, Mauritius, Puerto Rico and Queensland in Australia for germination

Table 2 Organisations involved in sugarcane improvement in Egypt

\begin{tabular}{|c|c|c|c|}
\hline Organisation & Funding source & Notes, key activities & Website/ email address \\
\hline $\begin{array}{l}\text { Sugar Crops Research Institute } \\
\text { (SCRI) }\end{array}$ & Government & $\begin{array}{l}\text { The only government agency. } \\
\text { Responsible for breeding, } \\
\text { producing and improving } \\
\text { new varieties of sugarcane }\end{array}$ & http://www.arc.sci.eg \\
\hline $\begin{array}{l}\text { Egyptian Sugar and Integrated } \\
\text { Industries Company (ESIIC) }\end{array}$ & Government & Responsible for sugar manufacture & https://www.siicegypt.com \\
\hline Sugar Crops Council & $\begin{array}{l}\text { Private-Governmenta } \\
\text { supervisory body }\end{array}$ & $\begin{array}{l}\text { Responsible for industry communication, } \\
\text { introduction of farm services for } \\
\text { sugarcane growers in cooperation } \\
\text { with SCRI and ESIIC }\end{array}$ & $\begin{array}{l}\text { https://gb.kompass.com/c/ } \\
\text { sugar-crops-council/eg032352/ }\end{array}$ \\
\hline
\end{tabular}

Table 3 History of sugarcane varieties in Egypt

\begin{tabular}{|c|c|c|c|c|}
\hline Cane variety & Date/duration & Country Source & Advantage & Reason for decline \\
\hline $\begin{array}{l}\text { 1. Jamaica varieties (red, red- } \\
\text { stripped and white) }\end{array}$ & $1892-1902$ & Jamaica & Early maturity & Diseases \\
\hline 2. M. 1030 & 1909 & Mauritius & Moderate length and ratoon & Streak and borers \\
\hline 3. POJ. 105 & $1905-1940$ & Indonesia & Moderate diameter, high length, good ratooning & Low sugar yield, low purity \\
\hline 4. POJ. 2878 & $1937-1967$ & Indonesia & High cane yield, strong growth & $\begin{array}{l}\text { Streak, borers, smut, poor } \\
\text { ratooning ability }\end{array}$ \\
\hline 5. Co. 281 & $1940-1943$ & India & Strong growth, good ratooning & Late maturity, smut \\
\hline 6. Co. 413 & $1947-1960$ & India & $\begin{array}{l}\text { High cane yield, good sugar content, good } \\
\text { ratooning }\end{array}$ & $\begin{array}{l}\text { Pith, borers, Smut, late } \\
\text { maturity }\end{array}$ \\
\hline 7- NCo310 & $1960-1980$ & South Africa & $\begin{array}{l}\text { High sugar content, high cane yield, early } \\
\text { maturity }\end{array}$ & $\begin{array}{l}\text { Smut, mosaic, poor } \\
\text { ratooning }\end{array}$ \\
\hline 9. G.T. 54-9 & 1983-Now & Egypt & $\begin{array}{l}\text { High sugar yield, high cane yield, stable in } \\
\text { ratoon, moderate to late maturity }\end{array}$ & - \\
\hline 10. G. $74-96$ & 1990 & Egypt & Resistance for smut, borers, mosaic & Poor ratooning \\
\hline 11. G. $35-37$ & 1990 & Egypt & Early maturity, resistance diseases & Poor ratooning \\
\hline 12. Ph. 8013 & 1998-2004 & Philippines & Higher cane and sugar yield than G.T. 54-9 & Poor ratooning \\
\hline 13. G. $84-47$ & 2009 & Egypt & $\begin{array}{l}\text { High cane and sugar yield, good ratooning, thin } \\
\text { diameter }\end{array}$ & Low sugar yield \\
\hline 14. G. $2003-47$ & 2016-Now & Egypt & $\begin{array}{l}\text { High sugar content than G.T. 54-9, high cane } \\
\text { yield, good ratooning }\end{array}$ & - \\
\hline
\end{tabular}


Table 4 Day length in Alexandria (mean of 5 years, 2013-2017)

\begin{tabular}{|c|c|c|c|c|c|}
\hline Date & Day length & Date & Day length & Date & Day length \\
\hline 01-Sep & $12: 47$ & 11-Sep & $12: 28$ & 21-Sep & $12: 10$ \\
\hline 02-Sep & $12: 45$ & 12-Sep & $12: 27$ & 22-Sep & $12: 08$ \\
\hline 03-Sep & $12: 44$ & 13-Sep & $12: 25$ & 23-Sep & $12: 06$ \\
\hline 04-Sep & $12: 41$ & 14-Sep & $12: 23$ & 24-Sep & $12: 05$ \\
\hline 05-Sep & $12: 40$ & 15-Sep & $12: 21$ & 25-Sep & $12: 03$ \\
\hline 06-Sep & $12: 38$ & 16-Sep & $12: 19$ & 26-Sep & $12: 01$ \\
\hline 07-Sep & $12: 36$ & 17-Sep & $12: 17$ & 27-Sep & $11: 59$ \\
\hline 08-Sep & $12: 34$ & 18-Sep & $12: 16$ & 28-Sep & $11: 57$ \\
\hline 09-Sep & $12: 32$ & 19-Sep & $12: 14$ & 29-Sep & $11: 55$ \\
\hline 10-Sep & $12: 31$ & 20-Sep & $12: 12$ & 30-Sep & $11: 53$ \\
\hline
\end{tabular}

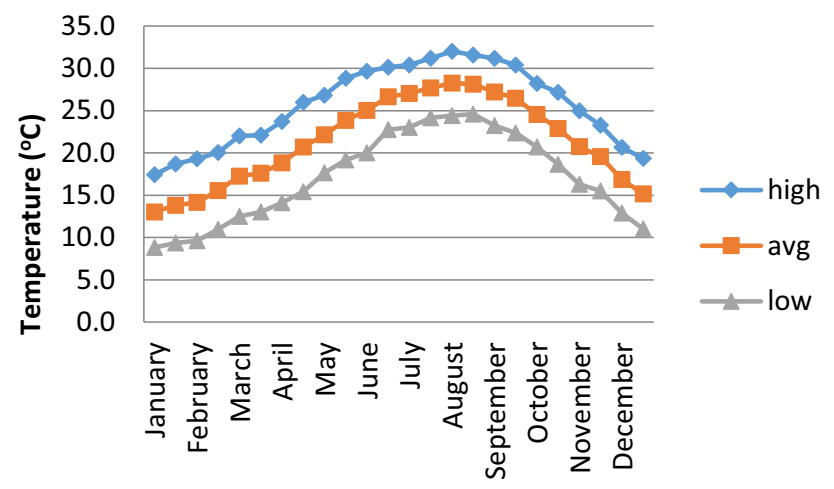

Fig. 1 Average monthly Air temperature in Alexandria (mean of 5 years, 2013-2017)

and selection under the Egyptian conditions. Importing of new commercial varieties and their evaluation were also continued.

In 1970, a Sugarcane Experimental Station was established in the Sabahia area of Alexandria (latitude of $31^{\circ}$ $12 \mathrm{~N}$ and longitude of $29^{\circ} 57 \mathrm{E}$ ), with the assistance of Dr. J. T. Rao (India). At this station, sugarcane was grown for natural open pollination, and seeds from cross-pollination were used for selection and release of several varieties since then.

\section{Overview of Current Sugarcane Breeding Program in Egypt}

The Egyptian Sugarcane Variety Development Program is accomplished through the genetic material available from the sugarcane germplasm collection in Egypt that flower locally for cross-hybridization and selection of desirable new sugarcane clones. Egyptian sugarcane breeding program is mainly focusing on enhancing sucrose percentage,

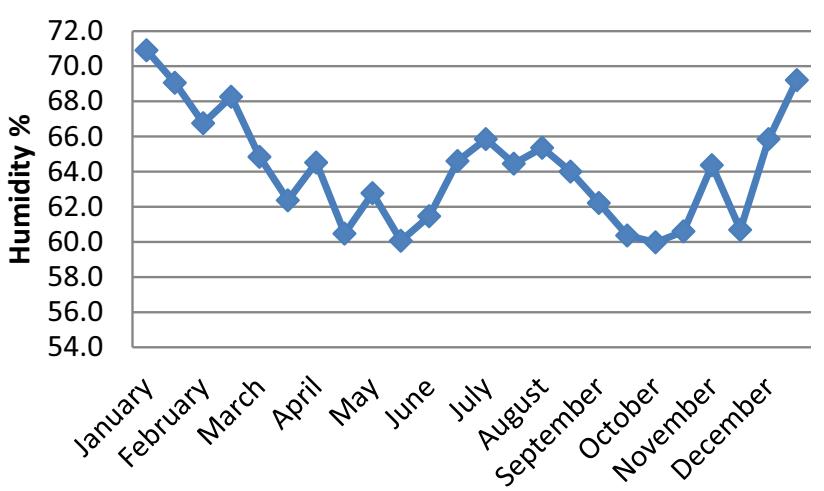

Fig. 2 Average monthly relative humidity \% in Alexandria (mean of 5 years, 2013-2017)

ratooning ability, high cane yield, and disease and insect resistance.

The variety development program begins with the flowering and hybridization stages, which is conducted at two sites exclusively. Crosses based on natural flowering are made at Sabahia Research Station, and crosses based on artificially induced flowering are made at Giza Research Station.

\section{Facilities of Flowering Station}

Sugar Crops Research Institute at Sabahia and Giza Station have well-qualified technical staff to conduct cane breeding. The following are the sugarcane breeding activities at SCRI and its agricultural experimental stations.

\section{Sabahia Experiment Station}

Natural flowering occurs under the conditions of the Sabahia station due to favourable climatic conditions (day length, temperature, and humidity). Flower induction occurs primarily during 15 days in September, where day 
Table 5 Selection stages at different stations in Egypt

\begin{tabular}{|c|c|c|c|}
\hline Year & Stage & Experimentation/selection & Location \\
\hline 1 & Hybridization & & Giza \\
\hline 2 & $\begin{array}{l}\text { Seedling } \\
\text { raising }\end{array}$ & $\begin{array}{l}\text { About } 5000 \text { sugarcane seedlings. Selection is based on stalk } \\
\text { diameter, brix, stalk weight and tillering. } 20-30 \% \text { of test clones } \\
\text { will be selected for the next stage of evaluation }\end{array}$ & Giza \\
\hline 3 & Clonal I & $\begin{array}{l}\text { Evaluation (about } 1000-1500 \text { clones) in single rows of } 3 \mathrm{~m} \text {, along } \\
\text { with GT } 54 / 9 \text { as check (local variety). Selection based on disease } \\
\text { incidence, tillers, pith, thickness, height, brix. About } 30 \% \text { of test } \\
\text { clones will be selected }\end{array}$ & Mattana (Luxor) \\
\hline 4 & Clonal II & $\begin{array}{l}\text { Trial of 300-450 clones from Clonal I stage with each clone grown } \\
\text { in singe row of } 6 \mathrm{~m} \text {. Selection based on millable canes, thickness, } \\
\text { height, brix, sucrose } \% \text { of plant crop and previous ratoon crop. } \\
\text { About } 20 \% \text { of test clones will be selected }\end{array}$ & Mattana (Luxor) \\
\hline 5 & Primary Trial & $\begin{array}{l}\text { Trial of Clonal II selections with each clone grown in } 6 \text { rows of } 7 \mathrm{~m} \\
\text { length. } 3 \text { reps, RCBD. GT54/9 Check. yield traits, plot yield, brix, } \\
\text { sucrose } \% \text {, commercial cane sugar content (CCS), reducing } \\
\text { sugars, diseases, ratoon data of previous stage. } 2 \text { ratoons, about } \\
90-100 \text { clones are evaluated }\end{array}$ & Mattana (Luxor) \\
\hline 6 & $\begin{array}{l}\text { Main } \\
\text { Experiment }\end{array}$ & $\begin{array}{l}\text { Trial of Clonal II selections with each clone grown in } 6 \text { rows of } 7 \mathrm{~m} \\
\text { length. RCBD, } 4 \text { reps. GT54/9 Check. yield traits, plot yield, brix, } \\
\text { sucrose \%, CCS, reducing sugars, diseases, ratoon data of } \\
\text { previous expt. } 2 \text { ratoons, about } 25-30 \text { clones are evaluated }\end{array}$ & $\begin{array}{l}\text { Mattana, Malawi (Minia governorate), Shandaweel } \\
\text { (Sohag governorate), Kom Ombo (Aswan } \\
\text { governorate) }\end{array}$ \\
\hline 7 & $\begin{array}{l}\text { Final } \\
\quad \text { Experiment }\end{array}$ & $\begin{array}{l}\text { 8-10 entries at this stage each grown in } 6 \text { rows of } 7 \mathrm{~m} \text { length. } \\
\text { RCBD, } 4 \text { reps. GT54/9 Check. Yield traits, plot yield, brix, } \\
\text { sucrose \%, CCS, reducing sugars, diseases, ratoon data of } \\
\text { previous expt. } 2 \text { ratoons.) }\end{array}$ & Mattana, Malawi, Shandaweel, Kom Ombo \\
\hline 8 & Demonstration & $\begin{array}{l}\text { The selections from the } 4 \text { stations are pooled and grown in } 10 \text { rows } \\
\text { of } 7 \mathrm{~m} \text { length. About } 1-2 \text { clone will be grown at this stage }\end{array}$ & At the Stations and Sugar factories \\
\hline
\end{tabular}

length reaches $12: 15-12: 40 \mathrm{~h}$, as shown in Table 4 and Figs. 1 and 2.

\section{Giza Station}

Two photoperiod rooms similar to those used in Louisiana, USA, are used to grow cane and produce flowers for crossing. Each photoperiod room can hold a total of 60 pots placed on two carts, with four stalks growing in each pot. The size of each photoperiod room is $8.1 \times 3.35 \times 6.5 \mathrm{~m}$, and the room temperature is controlled to keep the room temperature up to $24^{\circ} \mathrm{C}$ during the cold nights. A supplementary artificial light provided by twelve incandescent lamps of 250 watts each ensures the required photoperiodic treatments. These lamps are placed about $1.25 \mathrm{~m}$ above the upper stalk leaves. The out-of-door misting system consists of nozzles delivering tap water in the form of a fine mist spray, fixed about $5 \mathrm{~m}$ above ground level and operated daily from 10 am to $5 \mathrm{pm}$. Each crossing chamber is divided into 36 isolated crossing cubicles. Cubicle during crossing is kept at temperature at $23^{\circ} \mathrm{C}$ and humidity over $85 \%$. A seed germination chamber with heating and irrigation systems provides optimum conditions for seed germination and seedling growth. The research station annually produces $150-200$ hybrids.

\section{Selection Stages}

The breeding program includes three major stages of clonal selection (Table 5). The first stage (seedlings stage) occurs at Giza Station. The second (line stage) is conducted at ElMatana Research Station, and the third stage (advanced variety trials) is conducted at Malawi, Shandweel, ElMatana and Kom-Ombo Stations.

\section{Goals of Sugarcane Breeding Program}

\section{High Cane and Sugar Yields}

Data in Table 6 presents the description of some Egyptian sugarcane varieties. G. 98-28, G.T. 54-9, and G. 2003-47 are used in sugarcane breeding program as parents based on their high sugar content, aiming to produce progeny with higher sugar content. The variety G. 84-47, G. 98-28, and G. 2003-47 mature earlier than the other varieties. 
Table 6 List of current major cultivars in Egypt

\begin{tabular}{|c|c|c|c|c|}
\hline \multirow[t]{2}{*}{ Variety } & \multirow[t]{2}{*}{$\%$ of crop } & \multicolumn{2}{|l|}{ Parents } & \multirow[t]{2}{*}{ Notes on characteristics: good and bad features } \\
\hline & & Female & Male & \\
\hline G. $84-47$ & $>1 \%$ & 'NCo310’ & - & $\begin{array}{l}\text { Semi-prolific tillering, no flowering, excellent ratooning, erect, medium fibre content, } \\
\text { resistant to smut, borers and frost, high sugar and cane yield }\end{array}$ \\
\hline G. $99-160$ & Promising & $\begin{array}{r}\text { 'Cp.76- } \\
1306 \text { ' }\end{array}$ & $\begin{array}{l}\text { 'Q.76- } \\
1053 \text { ' }\end{array}$ & $\begin{array}{l}\text { Good tillering, no flowering, good ratooning, erect, medium fibre content, resistant to } \\
\text { smut, borers and frost, high sugar and cane yield }\end{array}$ \\
\hline G. $98-28$ & - & 'C34-33' & - & $\begin{array}{l}\text { Good tillering, no flowering, good ratooning, nil pith, erect, medium fibre content, } \\
\text { resistant to smut, borers and frost, high sugar and cane yield }\end{array}$ \\
\hline G.T.54-9 & $99 \%$ & 'NCo310’' & 'F. $337 / 925$ ' & $\begin{array}{l}\text { Good tillering, no flowering, good ratooning, nil pith, erect, medium fibre content, } \\
\text { resistant to smut and borers, frost tolerance, mid-late maturity, high sugar and cane } \\
\text { yield }\end{array}$ \\
\hline G. $2003-47$ & $\begin{array}{l}\text { New } \\
\quad \text { variety }>1 \%\end{array}$ & 'CP $55-30$ ' & 'CP $85-1697$ ' & $\begin{array}{l}\text { Good tillering, no flowering, good ratooning, nil pith, erect, medium fibre content, } \\
\text { resistant to smut, borers, frost tolerance, early maturity, highest sugar yield }\end{array}$ \\
\hline G. $2004-27$ & $\begin{array}{l}\text { New } \\
\quad \text { variety }>1 \%\end{array}$ & 'CP $55-30$ ' & 'RoC 22' & $\begin{array}{l}\text { Good tillering, no flowering, good ratooning, nil pith, erect, medium fibre content, } \\
\text { resistant to smut, borers, frost tolerance, mid-maturity, high sugar and cane yield }\end{array}$ \\
\hline G. $99-103$ & $>1 \%$ & 'US.74-3' & $\begin{array}{l}\text { 'CP.76- } \\
1055,\end{array}$ & $\begin{array}{l}\text { Good tillering, no flowering, good ratooning, nil pith, erect, medium fibre content, } \\
\text { resistant to smut, borers, frost tolerance, mid-maturity, highest cane yield }\end{array}$ \\
\hline
\end{tabular}

Good ratooning growth is an important attribute of sugarcane varieties, with 4-5 ratoon crops being common in commercial crops. Some growers may keep crops for more ratoons where there is good soil conditions and agricultural practices. G. $84-47$, G. $2003-47$ and G. 2004-27 have particularly good ratooning ability. In the sugarcane breeding program in Egypt, clones normally are evaluated through one or more ratoon crops in most stages of selection. Evaluation of ratoon crops in a multi-stage multi-location selection program significantly increases the time and resources needed for selection.

\section{Diseases and Pests}

Diseases and pests present a major challenge for the sugarcane industry in Egypt. Borers and soft scale insect are important sugarcane pests, and weeds cause large losses to cane and sugar yield. However, sugarcane smut is the most serious problem, causing losses of $20-60 \%$ in cane yield (Anonymous 2017).

\section{Conclusion}

The key objective of Egyptian Sugarcane Variety Breeding Program is to develop new genetically improved cultivars of sugarcane for an economically viable and environmentally sustainable Egyptian sugar industry. The success of sugarcane breeding program depends essentially on the selection of parents and identification of desirable clones for crop production. Increasingly, the breeder must focus on environmental conditions that affect production, such as biotic and abiotic stresses, in a country like Egypt. Water shortage is a major challenge facing Egyptian agriculture, especially after building the Renaissance Dam. Thus, it is inevitable that breeding programs must put more efforts for development of water use efficient and drought tolerant new varieties.

Supplementary Information The online version contains supplementary material available at https://doi.org/10.1007/ s12355-021-01010-5.

Open Access This article is licensed under a Creative Commons Attribution 4.0 International License, which permits use, sharing, adaptation, distribution and reproduction in any medium or format, as long as you give appropriate credit to the original author(s) and the source, provide a link to the Creative Commons licence, and indicate if changes were made. The images or other third party material in this article are included in the article's Creative Commons licence, unless indicated otherwise in a credit line to the material. If material is not included in the article's Creative Commons licence and your intended use is not permitted by statutory regulation or exceeds the permitted use, you will need to obtain permission directly from the copyright holder. To view a copy of this licence, visit http://creative commons.org/licenses/by/4.0/.

\section{References}

Anonymous 2017. Annual Report of Egyptian Sugar Crops Council. Sugar crops and sugar production in Egypt in 2015/2016 and 2017 seasons.

Anonymous 2019. Annual Report of Egyptian Sugar Crops Council 2019. Sugar crops and sugar production in Egypt in 2017/2018 and 2019 seasons.

USDA GAIN Report Egypt. 2019. Increasing sugar supply on expanded beet production, GAIN Report Number: EG-19006

Publisher's Note Springer Nature remains neutral with regard to jurisdictional claims in published maps and institutional affiliations. 